také již zvěčnělá prof. Danuše Kšicová zdůraznila $\mathrm{v}$ jednom jubilejním článku mimo jiné pragmatický aspekt její činnosti, ale to jistě nebylo všechno. Ti, kteří ji alespoň trochu znali, dobře vědí, že její práce byla nesena také obrovskou emocí, nadšením, srdcem. Doc. Lepilová měla ráda lidi, i když její životní cesta profesní nebyla přímočará: z Palackého univerzity musela $v$ roce 1990 odejít, na to se pamatuji velmi dobře a nechci se $\mathrm{k}$ tomu právě zde vracet; podobně i působení a předčasný odchod $\mathrm{v}$ plné síle z Ostravy nebyl projevem solidnosti př́slušných institucí, které se tak připravily o špičkovou odbornici. Když po roce 1990 hledala nové uplatnění a vrátila se vlastně do svého rodiště, byla to ona, kdo nabízela pracovní místa starším i mladým, za něž doslova dýchala: snad si na alespoň někteří vděčně vzpomenou. Dobře se na vše pamatuji a také na různé aktéry: jeden pracovník si po letech nemohl ani vzpomenout, jak se na jejím pracovišti vlastně ocitl. Právě po svém odchodu z Ostravy se na mě obrátila s nabídkou spolupráce, a tak byly položeny základy onoho brněnského projektu, ale ani to nebylo tak hladké, jak se některým dnes zdá: dobře se na to pamatuji. i když se na mnoho věcí už raději zapomnělo; pamět není silnou stránkou naší doby, ani této společnosti. Myslím, že její všestranná činnost nebyla dodnes doceněna. Mám ve zvyku si pamatovat a nezapomínat, zatímco paní docentka se naopak vždy dívala dopředu, uměla odpouštět a zapomínat zlé, i když nevím, jak to vše brala uvnitř̌: $\mathrm{v}$ tom byla její velkorysost, která charakterizuje velké lidi. Rusistika v řadě oblastí její nepřítomnost již nyní postrádá, mezeru, která jejím odchodem vznikla na poli lingvistiky, lingvodidaktiky, literární vědy a výchovy nelze zcela zacelit, nebot kreativní a charakterní lidé jsou nenahraditelní.

Ivo Pospíšil

https://doi.org/10.5817/NR2021-1-10

\section{Brněnské kolokvium - doktorská škola o Ivanu Gončarovovi}

V pořadí již čtvrté (dvakrát Leskov, jednou Dostojevskij) kolokvium se konalo jako mezinárodní doktorská škola pod záštitou děkana FF MU prof. Milana Pola 24. listopadu 2020, tentokrát online, po názvem Ivan Gončarov a evropský klasicismus a neoklasicismus. Doktorandi, resp. aspiranti a jejich učitelé/školitelé z České republiky, Ukrajiny a Ruska využívali různých metodologických postupů (projevily se tu metody literární komparatistiky, generální komparatistiky, genologie, naratologie, recepční estetiky, strukturní analýzy se stopami hermeneutiky aj.) pří zkoumání řady aspektů tvorby autora, která znovu v dnešní době ožívá - stejně jako v anglosaském světě např́iklad podobně založená Jane Austenová (1775-1817; prý právě o ní realistický satirik a humorista Mark Twain, vl. jm. Samuel Langhorne Clemens, $1835-1910$, řekl, že „Every library is good 
which does not contain the works of Jane Austen") - konzervatismus hodnot, úcta $\mathrm{k}$ formě a technologii tvorby, kult klidu a harmonie jako nejvyšší estetické hodnoty (zjevná návaznost na antické sofisty a Aristotela), úcta $\mathrm{k}$ tradici, odmítnutí chaosu a plodné návraty $\mathrm{k}$ antice a evropskému klasicismu 17. a 18. století, priorita kontinuity oproti diskontinuitě. Kolokvium zahájil jménem vedení Filozofické fakulty Masarykovy univerzity proděkan pro vědu prof. Petr Kyloušek, za organizátory vedoucí Ústavu slavistiky Ivo Pospíšil.

Ukrajinští účastníci (z univerzity v Černovicích, ukraj. Černivci, rus. Černovcy, rum. Cernăuți, kdysi centrum Bukoviny jako naší společné předlitavské vlasti, univerzitní komplex postavil v letech 1864-1882 známý český architekt Josef Hlávka jako rezidenci bukovinského metropolity), jejichž vedoucí Olha Červins'ka (Olga Červinskaja) kolokvium svým referátem zahájila, se orientovali na široké pojetí spisovatele, včetně jeho ukrajinské recepce (mimochodem: Není důvodem poměrně intenzivní recepce Gončarova na/v Ukrajině právě jeho „neoklasicismus“, který byl na Ukrajině v návaznosti na polský vliv relativně silný?). Ve vystoupení prof. Červinské s názvem Podle Puškinovy šablony: román Ivana Gončarova Všední přiběh (По пушкинскому лекалу: роман Ивана Гончарова «Обыкновенная история») je předmětem její hypotézy, snad i teorie je představa, že román je založen jako palimpsest známé Puškinovy strofy z Evžena Oněgina Блажен, кто смолоду был молод, Блажен, кто вовремя созрел (kapitola VIII., strofa X.). Autorka dokonce neváhá uvést, že jde o svéráznou cover verzi této strofy. Možná to tak s trochou hyperboly je. Rusisté z Jaroslavle se věnovali konkrétním dílům a jejich analýze; naprr. Tatjana Jur'jevová zkoumala cestopis Fregata Pallada v kontextu jiných ruckých travelogů, Natalja Luk'jančikovová si všímá dvou ženských postav z Leskovova románu Není kam jít / Nekuda a Gončarovovy Strže, černovický Roman Dzyk je právě tím, kdo obdivuhodně zmapoval - stejně jako předtím Leskova a Dostojevského - osudy Ivana Gončarova na Ukrajině. Královéhradecká rusistka původem z Volgogradu Galina Kosych srovnává kritické ohlasy na Gončarovovo dílo u M. A. Protopopova a N. Govoruchi-Otroka, Natalija Nikorjaková z Černovic zkoumá filmový scénář a jeho redukování sféry postav vzhledem k románu Oblomov; její ukrajinská kolegyně Aljona Tyčinovová zkoumá vyprávěcí způsoby (narativy) v románu Fregata Pallada (Нарратив личности автора в книге очерков И. Гончарова «Фрегат Паллада»), Tatjana Melniková z Moskvy analyzuje epistulární text jako reprezentativní znak kultury ve Strži, černovická badatelka Julija Isapčuk se zabývá imagologickou recepcí postavy Štolce v současnosti, Lenka Odehnalová (roz. Paučová) zkoumala Gončarova jako literárního kritika, autor této zprávy nazíral Gončarova v tradicích klasicismu s odvoláním na citát $\mathrm{z}$ Johanna Joachima Winckelmanna (1717-1768): 
„Edle Einfalt, stille Größe“ (vznešená prostota/jednoduchost, klidná velikost).

Klíčovou součástí kolokvia - doktorské školy byly diskuse a hlavně workshop, jímž se kolokvium uzavíralo. Rámcem zkoumání bylo sice to, co organizátoři navrhli při koncipování celé akce, tedy Gončarov na hraně romantismu a realismu, jeho profese cenzora, jeho činnost literárního kritika, roma- nopisce, ideologa a politika, cestovatele, autora tzv. antinihilistického románu, jeho pojetí literárních žánrů a hlavně prvky klasicistické poetiky $\mathrm{v}$ jeho díle, ale bádání a debaty probíhaly i po jiných liniích, hlavně recepce a vztahu k jiným druhům umění. Snad bude možné v těchto mezinárodních setkáních doktorandů a jejich učitelů pokračovat.

Ivo Pospišil 
